\title{
Formulasi dan Uji Sifat Fisik Sediaan Nanoemulsi Natrium Diklofenak dengan Kombinasi Tween 80 dan Transkutol
}

\author{
Formulation and Physical Properties Test of Sodium Diclofenac Nanoemulsion \\ with Combination Tween 80 and Transcutol \\ Lailiana Garna Nurhidayati ${ }^{1}$, Bambang Hernawan Nugroho ${ }^{2}$, Oktavia \\ Indrati $^{2}$ \\ ${ }^{I}$ Farmasi, Universitas Muhammadiyah Purwokerto \\ ${ }^{2}$ Farmasi, Universitas Islam Indonesia \\ ${ }^{1}$ lailianagarna@gmail.com
}

\begin{abstract}
ABSTRAK
Natrium diklofenak digunakan untuk nyeri dapat diberikan peroral, intramuskular dan suppositoria. Nanoemulsi dikembangkan untuk meningkatkan bioavailabilitas obat dalam tubuh. Nanoemulsi dibuat dengan mengkombinasikan fase minyak, fase air, surfaktan dan kosurfaktan. Fase minyak virgin coconut oil (VCO) dan kombinasi Tween 80 dan Transkutol sebagai surfaktan dan kosurfaktan dapat meningkatkan absorpsi perkutan melewati barrier kulit dan mukosal. Penelitian ini bertujuan untuk mengetahui formula terbaik untuk sediaan nanoemulsi natrium diklofenak dengan variasi konsentrasi Tween 80 dan Transkutol dan mengetahui pengaruh penambahan Transkutol sebagai kosurfaktan dalam sediaan nanoemulsi natrium diklofenak. Nanoemulsi dibuat dengan metode emulsifikasi spontan. Perbandingan surfaktan dengan kosurfaktan pada formula yang digunakan yaitu Formula 1 (5:1), Formula 2 (6:1), Formual 3 (7:1), dan Formula 4 (1:0). Hasil ukuran globul nanoemulsi Formula 1 10,9 nm; Formula 2 11,7 nm; Formula 3 7,1 nm; Formula 4 8,8 nm. Zeta potensial Formula $1-57,3 \mathrm{mV}$, Formula $2-63,0 \mathrm{mV}$, Formula $3-50,1 \mathrm{mV}$, Formula $4-27,6 \mathrm{mV}$. Hasil pH Formula 1 7,4 $\pm 0,032$; Formula 2 7,4 \pm 0,015 ; Formula 3 7,4 \pm 0,021; Formula $47,7 \pm 0,046$. Hasil viskositas Formula 1 $642,67 \pm 7,64 \mathrm{cP}$; Formula $2662,67 \pm 7,64 \mathrm{cP}$; Formula 3 715,00 $\pm 10,00 \mathrm{cP}$; Formula 4 $864,33 \pm 7,09 \mathrm{cP}$. Hasil sentrifugasi pada semua formula tidak mengalami pemisahan fase. Hasil dari semua uji menunjukkan Formula 1 merupakan formula terbaik dalam penampilan dan sifat fisik yang diuji.
\end{abstract}

Kata kunci: Nanoemulsi natrium diklofenak, Transkutol, Tween 80, Virgin Coconut Oil (VCO), Uji formulasi.

\begin{abstract}
Sodium diclofenac is used to relieve pain it's given orally, intramuscularly and suppository. Nanoemulsion developed to increase the bioavailability of the drug in the body. Nanoemulsion made with a combination of oil phase, water phase, surfactant, and cosurfactant. Combination of VCO, Tween 80 and Transcutol CG can increase the percutaneous absorption through barrier of skin and mucosal. This study aims to determine the effect of concentration Tween 80 and Transcutol in different variations to the permeation rates of nanoemulsion diclofenac sodium and determine the effect of Transcutol as cosurfactant in preparation nanoemulsion diclofenac sodium. Nanoemulsion was made by titration method. Ratio of surfactant and cosurfactant that used in each formula were Formula 1 (5: 1), Formula 2 (6: 1), Formula 3 (7: 1), and Formula 4 (1:0). The results of nanoemulsion globule size measurement were Formula 1
\end{abstract}


of $10.9 \mathrm{~nm}$; Formula $211.7 \mathrm{~nm}$; Formula $37.1 \mathrm{~nm}$; Formula $48.8 \mathrm{~nm}$. The result of zeta measurement were Formula $1-57,3 \mathrm{mV}$, Formula $2-63,0 \mathrm{mV}$, Formula $3-50,1 \mathrm{mV}$, Formula $4-27,6 \mathrm{mV}$. The result of $\mathrm{pH}$ measurement were Formula $17.413 \pm 0.032$; Formula $27.413 \pm 0.015$; Formula $37.407 \pm 0.021$; Formula $47.680 \pm 0.046$. The result of viscosity measurement were Formula $1642.67 \pm 7.64 \mathrm{cP}$; Formula $2662.67 \pm 7.64 \mathrm{cP}$; Formula $3715.00 \pm 10.00 \mathrm{cP}$; Formula $4864.33 \pm 7.09 \mathrm{cP}$. Centrifugation test at all formulas were not undergo phase separation. The results of all tests showed Formula 1 was the best formula in appearance and physical properties tested.

Key words: Nanoemulsion sodium diclofenac, transcutol, tween 80, virgin coconut oil (VCO), formulation test.

\section{PENDAHULUAN}

Natrium diklofenak adalah obat golongan NSAID (nonsteroidal anti inflamasi) yang memiliki sifat sebagai analgesik dan anti-inflamasi (Cooper and Harirforoosh, 2014). Natrium diklofenak digunakan untuk meringankan nyeri dan inflamasi rangka, penyakit sendi misalnya rheumatoid arthritis, osteoarthritis, dan spondylitis, dan kondisi non-inflamasi lainnya (Manconi et al., 2009). Mekanisme kerja natrium diklofenak adalah dengan cara menghambat enzim siklooksigenase (COX) agar tidak terbentuk prostaglandin sehingga mengurangi terbentuknya mediator nyeri di sistem syaraf tepi (Sweetman, 2007).

Natrium diklofenak tersedia dalam berbagai sediaan. Contohnya gel natrium diklofenak 1\%, gel natrium dietilamin 1,16\%, gel MIKA diklofenak spray 4\%, lotion diklofenak DMSO, dan patch diklofenak epolamin (diclofenac hydroxyethyl-pyrolidine). Pemberian topikal menunjukkan hasil konsentrasi yang tinggi di jaringan adiposa dan otot skeletal dibandingkan sediaan oral (Nair and Taylor-Gjevre, 2010). NSAID topikal merupakan bentuk pengembangan pengaplikasian obat secara lokal. Target dari pengembangan metode ini yaitu mengurangi absorpsi sistemik dan meminimalkan adanya kemungkinan efek toksik tanpa mengurangi efektivitas dari obat (Modi and Patel, 2011; Nair and Taylor-Gjevre, 2010).

\section{METODE}

\section{Alat}

Pada penelitian ini digunakan alat-alat yaitu timbangan analitik (Metler Toledo), gelas beker, batang pengaduk, jangka sorong, buret, mechanic strirrer, magnetic stirrer, shaking water (Memmert), pH meter (Metler Toledo), Viskometer KU2 (Brookfield), homogenizer, spektrofotometer UV, sentrifugator, dan Zetasizer nano ZS (Horiba SZ-100 ver2.00).

\section{Bahan}

Pada penelitian ini digunakan bahan-bahan yaitu Natrium Diklofenak (Lab. Teknologi Farmasi Univeristas Islam Indonesia), Virgin Coconut Oil (Lansida), Tween 80 (Lab. Teknologi Farmasi Univeristas Islam Indonesia), Transkutol (Lab. Teknologi Farmasi Universitas Islam Indonesia), metanol p.a (Merck), akuades (Lab. Teknologi Farmasi Universitas Islam Indonesia), akuabides (LPPT Universitas Gajah Mada), Kalium dihidrogen fosfat 0,2M (Merck), dan Natrium hidoksida 0,2M.

\section{Formula}


Pada penelitian ini dibuat 4 formula. Formula tersebut dibuat dengan mencampurkan natrium diklofenak, VCO, tween 80 , transkutol, dan akuabides. Formula lebih rincinya dapat diliat pada Tabel 1 .

Tabel 1. Formula sediaan nanoemulsi

\begin{tabular}{crrrr}
\hline Bahan & Formula I & Formula II & Formula III & Formula IV \\
\hline Na-Diklofenak & 1,00 gram & 1,00 gram & 1,00 gram & 1,00 gram \\
VCO & $3,23 \mathrm{~mL}$ & $3,23 \mathrm{~mL}$ & $3,23 \mathrm{~mL}$ & $3,23 \mathrm{~mL}$ \\
Tween 80 & $21,50 \mathrm{~mL}$ & $22,12 \mathrm{~mL}$ & $22,58 \mathrm{~mL}$ & $25,80 \mathrm{~mL}$ \\
Transkutol & $4,30 \mathrm{~mL}$ & $3,68 \mathrm{~mL}$ & $3,22 \mathrm{~mL}$ & - \\
Akuabides ad & $100,00 \mathrm{~mL}$ & $100,00 \mathrm{~mL}$ & $100,00 \mathrm{~mL}$ & $100,00 \mathrm{~mL}$ \\
\hline
\end{tabular}

\section{Penentuan kelarutan natrium diklofenak dalam fase minyak dan fase air}

Kelarutan natrium diklofenak dalam fase minyak dilakukan dengan cara ditimbang 1 gram natrium diklofenak, di ad $10 \mathrm{ml}$ minyak kelapa murni atau VCO sebagai fase minyak. Penentuan kelarutan natrium diklofenak dalam fase air dilakukan dengan cara menimbang 1 gram natrium diklofenak di ad $10 \mathrm{ml}$ aquabides. Digetarkan masing-masing tabung pada alat shaker selama 24 jam suhu $25^{\circ} \mathrm{C}$. Setelah 24 jam, tabung disentrifugasi dengan kecepatan 3000 rpm selama 5 menit. Diencerkan dengan metanol lalu disaring dengan kertas whatman 102. Dianalisis dengan spektrofotometer UV pada panjang gelombang maksimal.

\section{Pembuatan diagram fase}

Pembuatan diagram fase dilakukan menggunakan metode emulsifikasi spontan cairan dengan software ProSim Ternary Diagram. Data yang digunakan adalah formula yang dipilih dari hasil optimasi. Tujuan pembuatan diagram fase adalah umtuk melihat secara visual formula yang dipilih dalam penelitian berada pada area nanoemulsi.

\section{Uji Fisik}

\section{- Pengukuran globul nanoemulsi}

Pengukuran ukuran globul nanoemulsi dilakukan dengan alat Nanoparticle analyzer pada 1 hari setelah pembuatan nanoemulsi. Pengukuran dilakukan dengan cara $1 \mathrm{ml}$ sediaan nanoemulsi di ad $10 \mathrm{ml}$ akuabides pada suhu ruang dan dimasukkan ke dalam kuvet sampai tanda batas lalu dibaca di alat particle size analyzer. Hasil yang didapat berupa nilai ukuran globul dan indeks polidispersitas. Nilai indeks polidispersi merupakan rasio standar deviasi dari rata-rata ukuran droplet. Nilai indeks polidispersi yang besar menunjukkan keseragaman ukuran droplet dari formula yang rendah (Lovelyn and Attama, 2011).

\section{- Uji pH}

Alat uji pH meter dicelupkan dalam sediaan nanoemulsi dengan sebelumnya alat uji $\mathrm{pH}$ sudah dikalibrasi terlebih dahulu. Uji $\mathrm{pH}$ dilakukan untuk mengetahui apakah $\mathrm{pH}$ sediaan merupakan $\mathrm{pH}$ yang dapat diterima oleh kulit. Pada sediaan topikal, $\mathrm{pH}$ yang diterima oleh kulit tanpa menimbulkan iritasi yaitu 5,5-9 (Kaszuba et al., 2010).

\section{- Uji viskositas}

Uji viskositas dilakukan dengan viscometer Brookfield KU-2. Uji viskositas dilakukan untuk mengetahui kekentalan sediaan nanoemulsi. Semua formula dibuat tiga kali replikasi untuk uji viskositas ini.

\section{- Uji sentrifugasi}


Uji sentrifugasi dilakukan dengan alat sentrifugator dengan kecepatan $4000 \mathrm{rpm}$ selama 30 menit. Hasil uji sentrifugasi dikatakan baik dan stabil apabila tidak ada pemisahan setelah disentrifugasi. Setiap formula dibuat tiga kali replikasi. Diambil $10 \mathrm{ml}$ untuk tiap-tiap formula satu kali replikasi dan ditempatkan pada flakon yang tertutup rapat.

\section{Penetapan kadar natrium diklofenak dalam sediaan}

Pertama dibuat nanoemulsi tanpa natrium diklofenak (matriks nanoemulsi). Matriks nanoemulsi dibuat dengan jumlah yang sama dengan nanoemulsi dengan natrium diklofenak. Masing-masing matriks yang mewakili ketiga formula dibaca dengan perlakuan yang sama dengan sediaan nanoemulsi natrium diklofenak yaitu dengan menimbang 0,5 gram matriks dalam labu ukur $5 \mathrm{ml}$, lalu di ad dengan metanol p.a sampai tanda batas dan didapat kadar 1000 ppm. Diambil $140 \mu \mathrm{l}$ lalu di ad dalam labu $10 \mathrm{ml}$ dengan metanol p.a sehingga didapat kadar 14 ppm. Absorbansi dibaca menggunakan spektrofotometer UV.

\section{HASIL DAN PEMBAHASAN}

\section{Kelarutan natrium diklofenak dalam fase minyak dan fase air}

Kelarutan natrium diklofenak dalam fase minyak dilakukan untuk menentukan apakah natrium diklofenak dapat bercampur sempurna dengan fase minyak yang digunakan. Hasil kelarutan didapat bahwa untuk melarutkan 1 gram natrium diklofenak dibutuhkan 25,384 ml VCO dan 37,464 ml air. Hal tersebut menunjukkan bahwa natrium diklofenak lebih mudah larut dalam minyak. Natrium diklofenak memiliki kelarutan yang rendah dalam air, hal tersebut sesuai dengan literatur bahwa kelarutan diklofenak dalam air yaitu $0,02 \mathrm{mM}$ pada suhu $25^{\circ} \mathrm{C}$ (Manconi et al., 2011).

\section{Pembuatan diagram fase}

Tujuan pembuatan diagram fase adalah untuk melihat daerah nanoemulsi yang terbentuk dari sediaan nanoemulsi yang telah dibuat. Formula yang baik yaitu formula yang menghasilkan area terbesar pada diagram fase atau secara visual menghasilkan sediaan yang jernih mulai dari penambahan air di awal hingga penambahan air $100 \%$. Optimasi formula yang pertama dilakukan menggunakan perbandingan minyak dengan Smix 1:9 dengan perbandingan surfaktan dan kosurfaktan 1:1. Alasan pertama kali digunakan perbandingan minyak dengan Smix 1:9 karena pada literatur, perbandingan minyak banding Smix ini dari awal penambahan air sampai akhir menghasilkan sediaan jernih yang merupakan kriteria sediaan nanoemulsi (Shafiq-un-Nabi et al., 2007). Hasil pengamatan dari pertama penambahan air adalah keruh dan tidak transparan seperti nanoemulsi yang diharapkan. Sehingga optimasi dilanjutkan dengan perbandingan $1: 9(1: 2), 1: 9(2: 1), 1: 9(3: 1), 1: 9(5: 1), 1: 9(6: 1), 1: 9(7: 1)$. 1:9(8:1). 1:9(9:1). 1:8(1:1), $1: 8(2: 1), 1: 8(3: 1), 1: 8(4: 1), 1: 8(5: 1), 1: 8(6: 1), 1: 8(7: 1), 1: 7(3: 1)$, dan $1: 6(3: 1)$. Hasil pengamatan visual dari optimasi dapat dilihat pada Tabel 2 . 
Tabel 2. Pengamatan visual diagram fase pada berbagai macam perbandingan

\begin{tabular}{|c|c|c|c|c|c|c|c|c|c|c|c|c|c|c|c|c|c|c|}
\hline \multirow{2}{*}{$\begin{array}{c}\text { Rasio } \\
\text { minyak : } \\
\text { Smix (mL) }\end{array}$} & \multicolumn{18}{|c|}{ Penambahan air (mL) } \\
\hline & 1 & 1 & 0,5 & 1 & 1 & 1 & 1 & 1,5 & 2 & 2 & 3 & 3,5 & 5 & 6,5 & 10 & 15 & 35 & 110 \\
\hline$(1: 9) 1: 1$ & $\mathrm{~T}$ & $\mathrm{E}$ & E & E & E & E & E & E & E & E & E & E & $\mathrm{E}$ & E & E & E & E & E \\
\hline (1:9) $1: 2$ & $\mathrm{~T}$ & $\mathrm{E}$ & $\mathrm{E}$ & $\mathrm{E}$ & $\mathrm{E}$ & $\mathrm{E}$ & $\mathrm{E}$ & $\mathrm{E}$ & $\mathrm{E}$ & $\mathrm{E}$ & $\mathrm{E}$ & $\mathrm{E}$ & $\mathrm{E}$ & $\mathrm{E}$ & $\mathrm{E}$ & $\mathrm{E}$ & $\mathrm{E}$ & E \\
\hline (1:9) $2: 1$ & $\mathrm{~T}$ & $\mathrm{E}$ & $\mathrm{E}$ & $\mathrm{E}$ & $\mathrm{E}$ & $\mathrm{E}$ & $\mathrm{E}$ & $\mathrm{E}$ & $\mathrm{E}$ & $\mathrm{E}$ & $\mathrm{E}$ & $\mathrm{E}$ & $\mathrm{E}$ & $\mathrm{E}$ & $\mathrm{E}$ & $\mathrm{E}$ & $\mathrm{E}$ & $\mathrm{E}$ \\
\hline (1:9) $3: 1$ & $\mathrm{~T}$ & $\mathrm{~T}$ & $\mathrm{~T}$ & $\mathrm{~T}$ & $\mathrm{~T}$ & $\mathrm{~T}$ & $\mathrm{~T}$ & $\mathrm{E}$ & $\mathrm{E}$ & $\mathrm{E}$ & $\mathrm{E}$ & E & $\mathrm{E}$ & $\mathrm{E}$ & $\mathrm{E}$ & $\mathrm{E}$ & $\mathrm{E}$ & E \\
\hline (1:9) 5:1 & $\mathrm{T}$ & $\mathrm{T}$ & $\mathrm{T}$ & $\mathrm{T}$ & $\mathrm{T}$ & $\mathrm{T}$ & $\mathrm{T}$ & $\mathrm{T}$ & $\mathrm{T}$ & $\mathrm{E}$ & $\mathrm{E}$ & $\mathrm{E}$ & $\mathrm{E}$ & $\mathrm{E}$ & $\mathrm{E}$ & $\mathrm{E}$ & $\mathrm{E}$ & E \\
\hline (1:9) 6:1 & $\mathrm{T}$ & $\mathrm{T}$ & $\mathrm{T}$ & $\mathrm{T}$ & $\mathrm{T}$ & $\mathrm{T}$ & $\mathrm{T}$ & $\mathrm{T}$ & $\mathrm{T}$ & $\mathrm{T}$ & $\mathrm{T}$ & $\mathrm{T}$ & E & E & $\mathrm{E}$ & $\mathrm{E}$ & E & E \\
\hline (1:9) $7: 1$ & $\mathrm{~T}$ & $\mathrm{~T}$ & $\mathrm{~T}$ & $\mathrm{~T}$ & $\mathrm{~T}$ & $\mathrm{~T}$ & $\mathrm{~T}$ & $\mathrm{~T}$ & $\mathrm{~T}$ & $\mathrm{~T}$ & $\mathrm{~T}$ & $\mathrm{~T}$ & $\mathrm{~T}$ & $\mathrm{~T}$ & $\mathrm{~T}$ & $\mathrm{~T}$ & $\mathrm{~T}$ & $\mathrm{~T}$ \\
\hline (1:9) $8: 1$ & $\mathrm{~T}$ & $\mathrm{~T}$ & $\mathrm{~T}$ & $\mathrm{~T}$ & $\mathrm{~T}$ & $\mathrm{~T}$ & $\mathrm{~T}$ & $\mathrm{~T}$ & $\mathrm{~T}$ & $\mathrm{~T}$ & $\mathrm{~T}$ & $\mathrm{~T}$ & $\mathrm{~T}$ & $\mathrm{~T}$ & $\mathrm{~T}$ & $\mathrm{~T}$ & $\mathrm{~T}$ & $\mathrm{~T}$ \\
\hline \multirow[t]{2}{*}{ (1:9) $9: 1$} & $\mathrm{~T}$ & $\mathrm{~T}$ & $\mathrm{~T}$ & $\mathrm{~T}$ & $\mathrm{~T}$ & $\mathrm{~T}$ & $\mathrm{~T}$ & $\mathrm{~T}$ & $\mathrm{~T}$ & $\mathrm{~T}$ & $\mathrm{~T}$ & $\mathrm{~T}$ & $\mathrm{~T}$ & $\mathrm{~T}$ & $\mathrm{~T}$ & $\mathrm{~T}$ & $\mathrm{~T}$ & $\mathrm{~T}$ \\
\hline & 2 & 1,2 & 1,3 & 1,5 & 1,8 & 1,9 & 2,3 & 2,7 & 3,3 & 4 & 5 & 6,5 & 8,5 & 12 & 18 & 30 & 60 & 180 \\
\hline (1:8) 1:0* & $\mathrm{T}$ & $\mathrm{T}$ & $\mathrm{T}$ & $\mathrm{T}$ & $\mathrm{T}$ & $\mathrm{T}$ & $\mathrm{T}$ & $\mathrm{T}$ & $\mathrm{T}$ & $\mathrm{T}$ & $\mathrm{T}$ & $\mathrm{T}$ & $\mathrm{T}$ & $\mathrm{T}$ & $\mathrm{T}$ & $\mathrm{T}$ & $\mathrm{T}$ & $\mathrm{T}$ \\
\hline (1:8) 3:1 & $\mathrm{T}$ & $\mathrm{T}$ & E & E & E & $\mathrm{E}$ & $\mathrm{E}$ & $\mathrm{E}$ & $\mathrm{E}$ & E & $\mathrm{E}$ & E & $\mathrm{E}$ & E & E & E & $\mathrm{E}$ & E \\
\hline (1:8) 3:1 & $\mathrm{T}$ & $\mathrm{T}$ & $\mathrm{T}$ & $\mathrm{T}$ & E & $\mathrm{E}$ & E & $\mathrm{E}$ & $\mathrm{E}$ & E & $\mathrm{E}$ & E & $\mathrm{E}$ & E & E & E & $\mathrm{E}$ & E \\
\hline (1:8) 3:1 & $\mathrm{T}$ & $\mathrm{T}$ & $\mathrm{T}$ & $\mathrm{T}$ & $\mathrm{T}$ & $\mathrm{E}$ & $\mathrm{E}$ & $\mathrm{E}$ & $\mathrm{E}$ & $\mathrm{E}$ & $\mathrm{E}$ & E & E & E & $\mathrm{E}$ & $\mathrm{E}$ & $\mathrm{E}$ & E \\
\hline (1:8) 4:1 & $\mathrm{T}$ & $\mathrm{T}$ & $\mathrm{T}$ & $\mathrm{T}$ & $\mathrm{T}$ & $\mathrm{T}$ & $\mathrm{T}$ & $\mathrm{T}$ & $\mathrm{T}$ & E & E & E & E & E & $\mathrm{E}$ & $\mathrm{E}$ & E & E \\
\hline (1:8) $5: 1^{*}$ & $\mathrm{~T}$ & $\mathrm{~T}$ & $\mathrm{~T}$ & $\mathrm{~T}$ & $\mathrm{~T}$ & $\mathrm{~T}$ & $\mathrm{~T}$ & $\mathrm{~T}$ & $\mathrm{~T}$ & $\mathrm{~T}$ & $\mathrm{~T}$ & $\mathrm{~T}$ & $\mathrm{~T}$ & $\mathrm{~T}$ & $\mathrm{~T}$ & $\mathrm{~T}$ & $\mathrm{~T}$ & $\mathrm{~T}$ \\
\hline$(1: 8) 6: 1^{*}$ & $\mathrm{~T}$ & $\mathrm{~T}$ & $\mathrm{~T}$ & $\mathrm{~T}$ & $\mathrm{~T}$ & $\mathrm{~T}$ & $\mathrm{~T}$ & $\mathrm{~T}$ & $\mathrm{~T}$ & $\mathrm{~T}$ & $\mathrm{~T}$ & $\mathrm{~T}$ & $\mathrm{~T}$ & $\mathrm{~T}$ & $\mathrm{~T}$ & $\mathrm{~T}$ & $\mathrm{~T}$ & $\mathrm{~T}$ \\
\hline$(1: 8) 7: 1^{*}$ & $\mathrm{~T}$ & $\mathrm{~T}$ & $\mathrm{~T}$ & $\mathrm{~T}$ & $\mathrm{~T}$ & $\mathrm{~T}$ & $\mathrm{~T}$ & $\mathrm{~T}$ & $\mathrm{~T}$ & $\mathrm{~T}$ & $\mathrm{~T}$ & $\mathrm{~T}$ & $\mathrm{~T}$ & $\mathrm{~T}$ & $\mathrm{~T}$ & $\mathrm{~T}$ & $\mathrm{~T}$ & $\mathrm{~T}$ \\
\hline \multirow{3}{*}{$(1: 7) 3: 1$} & 1,8 & 1,2 & 1 & 1,4 & 1,6 & 1,6 & 2,1 & 2,8 & 2,5 & 3,6 & 4,4 & 6 & 7,5 & 11 & 16 & 26 & 53 & 160 \\
\hline & $\mathrm{T}$ & $\mathrm{T}$ & $\mathrm{T}$ & $\mathrm{T}$ & $\mathrm{E}$ & $\mathrm{E}$ & $\mathrm{E}$ & $\mathrm{E}$ & $\mathrm{E}$ & $\mathrm{E}$ & $\mathrm{E}$ & E & $\mathrm{E}$ & $\mathrm{E}$ & $\mathrm{E}$ & $\mathrm{E}$ & $\mathrm{E}$ & $\mathrm{E}$ \\
\hline & 1,6 & 0,9 & 1 & 1,2 & 1,3 & 1,6 & 1,7 & 2,2 & 2,5 & 3,2 & 3,8 & 5 & 7 & 9 & 14 & 24 & 46 & 140 \\
\hline$(1: 6) 3: 1$ & $\mathrm{~T}$ & $\mathrm{~T}$ & $\mathrm{~T}$ & $\mathrm{E}$ & $\mathrm{E}$ & $\mathrm{E}$ & $\mathrm{E}$ & $\mathrm{E}$ & $\mathrm{E}$ & $\mathrm{E}$ & $\mathrm{E}$ & E & $\mathrm{E}$ & E & $\mathrm{E}$ & $\mathrm{E}$ & $\mathrm{E}$ & $\mathrm{E}$ \\
\hline
\end{tabular}

Keterangan:

Daerah arsir: Tujuh formula yang menghasilkan tampilan transparan

*: Formula yang digunakan dalam penelitian

T: Transparan

E: Emulsi/keruh

Hasil optimasi yang menunjukkan sediaan transparan yaitu pada perbandingan 1:9(7:1). 1:9(8:1). 1:9(9:1), 1:8(5:1), 1:8(6:1), dan 1:8(7:1). Selanjutnya dilakukan formulasi, yaitu hasil perbandingan yang menghasilkan sediaan transparan dibuat ulang dan ditambah dengan natrium diklofenak. Pada perbandingan 1:9(7:1) menghasilkan sediaan yang keruh dan tidak transparan. Maka untuk formula yang dipakai dipilih perbandingan yang menghasilkan sediaan transparan dan yang memiliki sedikit jumlah tween 80 dengan mempertimbangkan tween 80 yang tidak menimbulkan iritasi kulit yaitu perbandingan 1:8(5:1), 1:8(6:1), dan 1:8(7:1). Diagram fase dibuat dengan menggunakan software ProSim Ternary Diagram. Data yang dimasukkan ke dalam software ProSim Ternary Diagram adalah perbandingan minyak banding Smix 1:8.

\section{Sediaan nanoemulsi}

Pembuatan nanoemulsi natrium diklofenak menggunakan cara titrasi metode emulsifikasi spontan. Titrasi yaitu metode untuk membuat nanoemulsi menggunakan sedikit energi. Keuntungan menggunakan sedikit energi yaitu karena tidak membutuhkan 
alat khusus, biaya pembuatan yang lebih sedikit, dan proses pembuatannya yang mudah. Metode pembuatan nanoemulsi dengan energi sedikit dibagi menjadi dua tipe, yaitu metode isotermal dan metode termal. Metode isotermal dibagi menjadi dua jenis, yaitu spontaneous emulsification dan emulsion phase inversion (Mura et al., 2000). Proses pembuatan nanoemulsi pada pertengahan penambahan air, sediaan melewati bicontinous phase yaitu terbentuknya gel ditengah-tengah proses titrasi, namun setelah dilanjutkan penambahan air gel tersebut mulai menghilang dan terbentuk massa emulsi yang baik. Tampilan sediaan nanoemulsi natrium diklofenak setelah dibuat dapat dilihat pada Gambar 1.

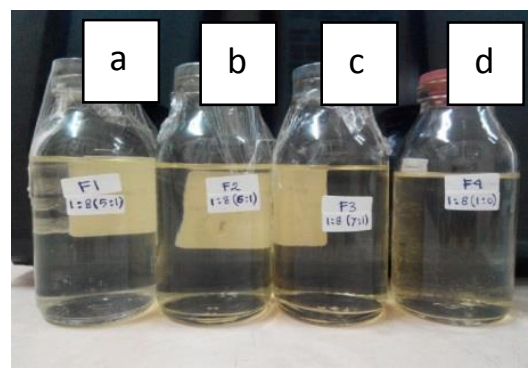

Gambar 1. Sediaan nanoemulsi natrium diklofenak. (a) Tween 80:Transkutol 5:1; (b) Tween 80:Transkutol 6:1; (c) Tween 80:Transkutol 7:1; (d) Tween 80:Transkutol 1:0

\section{Pengukuran ukuran globul nanoemulsi}

Globul nanoemulsi natrium diklofenak diukur menggunkan alat zetasizer (Horiba SZ-100 ver2.00). Nilai ukuran globul dipengaruhi dari bahan yang digunakannya. Salah satunya yaitu agen pengemulsi. Agen pengemulsi menghasilkan nanoemulsi yang baik dipilih dengan nilai HLB 8-18 (Zhang et al., 2014). Ukuran globul masing-masing formula dapat dilihat pada tabel 3. Formula 1, 2, 3 dan 4 berturut-turut memiliki perbandingan surfaktan dan kosurfaktan 5:1, 6:1, 7:1, dan 1:0. Formula 4 merupakan formula pembanding, yaitu formula yang tidak menggunakan kosurfaktan.

Tabel 3. Ukuran partikel sediaan nanoemulsi natrium diklofenak

\begin{tabular}{ccc}
\hline Formula & Ukuran partikel $(\mathrm{nm})$ & Polidispersi indeks \\
\hline 1 & 10,9 & 0,504 \\
2 & 11,7 & 0,536 \\
3 & 7,1 & 0,448 \\
4 & 8,8 & 0,492 \\
\hline
\end{tabular}

Keterangan:

FI : Formula nanoemulsi dengan perbandingan Tween 80:Transcutol=5:1

F2: Formula nanoemulsi dengan perbandingan Tween 80:Transcutol=6:1

F3: Formula nanoemulsi dengan perbandingan Tween 80:Transcutol=7:1

F4: Formula nanoemulsi dengan perbandingan Tween 80:Transcutol=1:0

Teknik pengukuran ukuran globul pada alat zetasizer menggunakan metode dynamic light scettaring (DLS). DLS adalah teknik hamburan sinar laser yang mampu menganalisis distribusi ukuran partikel dalam rentang nanometer sampai mikron. Prinsip kerjanya ketika sinar cahaya koheren menyebar akibat gerak brown, adanya gangguan menyebabkan fluktuasi dalam pembacaan. Gerak brown dipengaruhi oleh ukuran partikel, viskositas, dan suhu (Streets et al., 2013). Secara visual, semua formula memiliki penampakan transparan, sedikit berwarna kuning yang disebabkan oleh warna Tween 
80 yang berwarna kuning. Setelah 2 minggu sediaan yang terbentuk tetap transparan, hal tersebut menunjukkan sediaan dari semua formula stabil dalam suhu ruang $25^{\circ} \mathrm{C}$.

Semakin kecil nilai polidispersi indeks menunjukkan sediaan dapat bertahan secara stabil dalam jangka waktu yang panjang. Nilai polidispersi indeks dapat dilihat pada tabel 4 . Berdasarkan tipe nilai polidispersi indeks, maka semua formula memiliki nilai polispersi indeks antara 0,08-0,7 yang artinya semua formula memiliki algoritma distribusi yang beroperasi paling baik. Hal tersebut membuktikan semua formula yang dibuat dapat bertahan lama secara stabil.

Tabel 4. Polydispersity Index Value (Danaei et al., 2018)

\begin{tabular}{cl}
\hline Nilai PDI & \multicolumn{1}{c}{ Keterangan } \\
\hline$<0,05$ & Monodispersi \\
$<0,08$ & Mendekati monodispersi \\
$0,08-0,7$ & Algoritma distribusi partikel beroperasi paling baik. \\
$>0,07$ & $\begin{array}{l}\text { Polidispersi. Distribusi partikel sangat luas dan } \\
\text { dimungkinkan terjadi sedimentasi. }\end{array}$ \\
\hline
\end{tabular}

\section{Pengukuran zeta potensial}

Zeta potensial merupakan parameter kontrol interaksi elektrostatik dari dispersi partikel. Nilai zeta potensial dapat menjadi prediksi stabilitas jangka panjang dari sediaan. Nilai zeta potensial yang baik yaitu $-30 \leq$ atau $\geq 30$ (Kaszuba et al., 2010). Nilai tersebut dikatakan baik karena zeta potensial kecil negatif atau besar positif akan menyebabkan adanya gerakan saling tolak menolak antar partikel dan dispersi sediaan akan stabil. Sedangkan jika partikel memiliki nilai zeta potensial besar negatif dan kecil positif maka tidak ada kekuatan untuk mencegah partikel untuk saling berkumpul dan menyebabkan dispersi yang tidak stabil. Nilai zeta potensial dipengaruhi salah satunya oleh adanya muatan yang terkandung didalam sediaan. Tween 80 merupakan surfaktan nonionik, yaitu surfaktan yang tidak memiliki muatan pada ujung gugus alkilnya. Maka penggunaan tween 80 biasanya akan membuat sediaan memiliki nilai zeta yang rendah. Pada formula yang dibuat pada penelitian ini, nilai zeta potensial lebih dipengaruhi oleh muatan pada transcutol. Muatan yang terkandung didalam transcutol mempengaruhi besar kecil nilai zeta potensial sediaan. Gugus $\mathrm{OH}^{-}$membuat sediaan memiliki nilai zeta negatif, sedangkan adanya gugus $\mathrm{H}^{+}$membuat sediaan memiliki nilai zeta positif. Nilai zeta potensial dari semua formula dapat dilihat pada tabel 5. Formula 1 memiliki paling besar nilai zeta. Hal tersebut dapat dikarenakan jumlah Tween 80 yang terkandung didalam formula 1 paling sedikit. Sehingga semakin sedikit Tween 80 yang ditambahkan maka nilai zeta semakin tinggi.

Tabel 5. Zeta potensial

\begin{tabular}{cc}
\hline Formula & Zeta potensial $(\mathbf{m V})$ \\
\hline 1 & $-57,3$ \\
2 & $-63,0$ \\
3 & $-50,1$ \\
4 & $-27,6$ \\
\hline
\end{tabular}

Keterangan:

FI : Formula nanoemulsi dengan perbandingan Tween 80:Transcutol=5:1

F2: Formula nanoemulsi dengan perbandingan Tween 80:Transcutol=6:1

F3: Formula nanoemulsi dengan perbandingan Tween 80:Transcutol=7:1

F4: Formula nanoemulsi dengan perbandingan Tween 80:Transcutol=1:0 


\section{Uji pH}

Derajat keasaman atau $\mathrm{pH}$ merupakan suatu nilai yang digunakan untuk menyatakan tingkat keasaman atau kebasaan yang dimiliki oleh suatu zat, larutan, atau benda. Tujuan dilakukan uji $\mathrm{pH}$ yaitu untuk mengetahui tingkat keasaman dari sediaan nanoemulsi natrium diklofenak. Nilai $\mathrm{pH}$ yang dapat ditoleransi kulit yaitu 5,5-9 (Da Costa et al., 2014). Sediaan dengan nilai $\mathrm{pH}$ diluar rentang tersebut dikhawatirkan dapat mengiritasi kulit. Nilai $\mathrm{pH}$ dari semua formula menunjukkan hasil yang baik untuk dijadikan sediaan topikal, karena nilai $\mathrm{pH}$ dari semua formula masuk dalam rentang $\mathrm{pH}$ sediaan yang aman sehingga tidak mengiritasi kulit. Nilai $\mathrm{pH}$ dari semua formula dapat dilihat pada Tabel 6 .

Tabel 6. Nilai pH sediaan nanoemulsi natrium diklofenak

Keterangan : $*=\overline{\mathrm{X} \pm \mathrm{SD}}$

\begin{tabular}{cc}
\hline Formula & Nilai pH* \\
\hline Formula 1 & $7,413 \pm 0,032$ \\
Formula 2 & $7,413 \pm 0,015$ \\
Formula 3 & $7,407 \pm 0,021$ \\
Formula 4 & $7,680 \pm 0,046$ \\
\hline
\end{tabular}

F1: Formula nanoemulsi dengan perbandingan Tween 80:Transcutol=5:1

F2: Formula nanoemulsi dengan perbandingan Tween 80:Transcutol=6:1

F3: Formula nanoemulsi dengan perbandingan Tween 80:Transcutol=7:1

F4: Formula nanoemulsi dengan perbandingan Tween 80:Transcutol=1:0

Uji pH di analisis menggunakan uji statistik. Hasil uji one way annova menunjukkan $\mathrm{P}<0,05$. Hasil tersebut menunjukkan bahwa antar formula terdapat perbedaan signifikan dalam uji pH. Maka dilanjutkan uji Post Hoc Dari uji Post Hoc menunjukkan adanya perbedaan yang bermakna dari hasil uji $\mathrm{pH}$ pada formula 1 dengan formula 4 dengan nilai signifikansi 0,000 , formula 2 dengan formula 4 dengan nilai signifikansi 0,000, dan formula 3 dengan formula 4 dengan nilai signifikansi 0,000 .

\section{Uji Viskositas}

Viskositas merupakan ukuran kekentalan yang menyatakan besar kecilnya gesekan dalam fluida. Alat yang digunakan pada uji viskositas sediaan nanoemulsi natrium diklofenak adalah viscometer Brookfield tipe KU-2. Nilai viskositas yang besar menunjukkan sediaan yang kental. Formula yang memiliki nilai viskositas terbesar yaitu formula 4. Nilai viskositas dari yang terbesar yaitu formula 4, formula 3, formula 2, lalu formula 1. Formula 4 memiliki kekentalan lebih besar dibanding formula lain karena formula 4 mengadung Tween 80 yang lebih banyak dibanding formula lain. Semakin banyak jumlah Tween 80 yang ditambahkan, semakin kental sediaan yang terbentuk. Karena Tween 80 merupakan larutan kental. Tween 80 memiliki nilai viskositas sebesar $425 \mathrm{cP}$ (Rowe et al., 2009). Nilai viskositas dari semua formula dapat dilihat pada tabel 7.

Tabel 7. Viskositas sediaan nanoemulsi natrium diklofenak

\begin{tabular}{cc}
\hline Formula & Viskositas $(\mathbf{c P})^{*}$ \\
\hline Formula 1 & $642,67 \pm 7,64$ \\
Formula 2 & $662,67 \pm 7,64$ \\
Formula 3 & $715,00 \pm 10,00$ \\
Formula 4 & $864,33 \pm 7,09$ \\
\hline
\end{tabular}




\begin{abstract}
Keterangan $: *=\mathrm{X} \pm \mathrm{SD}$
F1: Formula nanoemulsi dengan perbandingan Tween 80:Transcutol=5:1

F2: Formula nanoemulsi dengan perbandingan Tween 80 :Transcutol $=6: 1$

F3: Formula nanoemulsi dengan perbandingan Tween 80 :Transcutol=7:1

F4: Formula nanoemulsi dengan perbandingan Tween 80:Transcutol=1:0
\end{abstract}

\title{
8. Uji Sentrifugasi
}

Tujuan dilakukan uji sentrifugasi adalah untuk mengetahui kestabilan sediaan nanoemulsi natrium diklofenak dengan adanya guncangan yang sangat tinggi. Hasil uji sentrifugasi menunjukan stabilitas termodinamika dari sediaan, dimana ketahanan sediaan dalam waktu yang lama tanpa mengalami pemisahan fase (Azeem et al., 2009). Sediaan dikatakan stabil apabila tidak terjadi pemisahan fase. Uji sentrifugasi dilakukan dengan alat sentrifugator dengan kecepatan 4000 rpm selama 30 menit. Setiap formula dibuat tiga replikasi. Hasil uji sentrifugasi pada semua formula tidak terjadi pemisahan fase. Jadi dari hasil tersebut dapat dikatakan semua formula sediaan nanoemulsi natrium diklofenak stabil terhadap pengaruh kekuatan fisik.

\section{Penetapan kadar natrium diklofenak dalam sediaan}

Penetapan kadar natrium diklofenak dalam sediaan dilakukan untuk melihat kadar natrium diklofenak yang ditambahkan diawal pembuatan sediaan berkurang atau tidak selama proses pembuatan sediaan. Penetapan kadar dilakukan menggunakan spektrofotometer uv dengan panjang gelombang $282 \mathrm{~nm}$. Konsentrasi sebenarnya dihitung dengan menggunakan kurva kalibrasi natrium diklofenak dalam pelarut metanol yaitu dengan persamaan $\mathrm{y}=0,0364 \mathrm{x}-0,0398$ dengan sebelumnya melakukan pengurangan absorbansi terukur dengan absorbansi matriks yang telah didapat sebelumnya. Nilai persen kadar natrium diklofenak dapat dilihat pada tabel 8. Hasil persen kadar yang didapat sudah baik, karena persen kadar natrium diklofenak yang dapat diterima yaitu $100 \% \pm 10 \%$. Hal tersebut bermakna selama proses pembuatan sediaan nanoemulsi natrium diklofenak tidak terjadi pengurangan kadar natrium diklofenak yang bermakna.

Tabel 8. Persen kadar narium diklofenak dalam sediaan

\begin{tabular}{cccc}
\hline Data & Kadar (\%) & Rata-rata (\%) & SD \\
\hline F1 R1 & 102,198 & & \\
F1 R2 & 101,805 & 102,07 & 0,227 \\
F1 R3 & 102,198 & & \\
\hline F2 R1 & 100,824 & & \\
F2 R2 & 100,628 & 101,02 & 0,519 \\
F2 R3 & 101,609 & & \\
\hline F3 R1 & 101,413 & & \\
F3 R2 & 101,609 & 101,61 & \\
F3 R3 & 101,805 & & 0,196 \\
F4 R1 & 95,330 & & \\
F4 R2 & 95,133 & 95,20 & \\
F4 R3 & 95,133 & & \\
\hline
\end{tabular}


Keterangan:

FI : Formula nanoemulsi dengan perbandingan Tween 80:Transcutol=5:1

F2: Formula nanoemulsi dengan perbandingan Tween 80 :Transcutol=6:1

F3: Formula nanoemulsi dengan perbandingan Tween 80 :Transcutol=7:1

F4: Formula nanoemulsi dengan perbandingan Tween 80:Transcutol=1:0

\section{KESIMPULAN}

Variasi konsentrasi Tween 80 dan Transcutol dapat mempengaruhi sifat fisika sediaan nanoemulsi natrium diklofenak. Variasi konsentrasi tween 80 dan transkutol yang tepat dapat membentuk sediaan nanaoemulsi yang baik dan stabil.

\section{DAFTAR PUSTAKA}

Azeem, A., Rizwan, M., Ahmad, F.J., Iqbal, Z., Khar, R.K., Aqil, M., Talegaonkar, S., 2009. Nanoemulsion Components Screening and Selection: a Technical Note. AAPS PharmSciTech 10, 69-76. https://doi.org/10.1208/s12249-008-9178-x

Cooper, D.L., Harirforoosh, S., 2014. Design and Optimization of PLGA-Based Diclofenac Loaded Nanoparticles. PLoS ONE 9, e87326. https://doi.org/10.1371/journal.pone.0087326

Da Costa, S., Basri, M., Shamsudin, N., Basri, H., 2014. Stability of Positively Charged Nanoemulsion Formulation Containing Steroidal Drug for Effective Transdermal Application. J. Chem. 2014, 1-8. https://doi.org/10.1155/2014/748680

Danaei, M., Dehghankhold, M., Ataei, S., Hasanzadeh Davarani, F., Javanmard, R., Dokhani, A., Khorasani, S., Mozafari, M., 2018. Impact of Particle Size and Polydispersity Index on the Clinical Applications of Lipidic Nanocarrier Systems. Pharmaceutics 10, 57. https://doi.org/10.3390/pharmaceutics10020057

Kaszuba, M., Corbett, J., Watson, F.M., Jones, A., 2010. High-concentration zeta potential measurements using light-scattering techniques. Philos. Trans. R. Soc. Math. Phys. Eng. Sci. 368, 4439-4451. https://doi.org/10.1098/rsta.2010.0175

Lovelyn, C., Attama, A.A., 2011. Current State of Nanoemulsions in Drug Delivery. J. Biomater. Nanobiotechnology $\quad 02, \quad 626-639$. https://doi.org/10.4236/jbnb.2011.225075

Manconi, M., Caddeo, C., Sinico, C., Valenti, D., Mostallino, M.C., Biggio, G., Fadda, A.M., 2011. Ex vivo skin delivery of diclofenac by transcutol containing liposomes and suggested mechanism of vesicle-skin interaction. Eur. J. Pharm. Biopharm. 78, 27-35. https://doi.org/10.1016/j.ejpb.2010.12.010

Manconi, M., Mura, S., Sinico, C., Fadda, A.M., Vila, A.O., Molina, F., 2009. Development and characterization of liposomes containing glycols as carriers for diclofenac. Colloids Surf. Physicochem. Eng. Asp. 342, 53-58. https://doi.org/10.1016/j.colsurfa.2009.04.006

Modi, J.D., Patel, J.K., 2011. Nanoemulsion-Based Gel Formulation of Aceclofenac for Topical Delivery 7.

Mura, P., Faucci, M.T., Bramanti, G., Corti, P., 2000. Evaluation of transcutol as a clonazepam transdermal permeation enhancer from hydrophilic gel formulations. Eur. J. Pharm. Sci. 9, 365-372. https://doi.org/10.1016/S0928-0987(99)00075-5

Nair, B., Taylor-Gjevre, R., 2010. A Review of Topical Diclofenac Use in Musculoskeletal Disease. Pharmaceuticals 3, 1892-1908. https://doi.org/10.3390/ph3061892 
Rowe, R., Sheskey, P., Quinn, M., 2009. Handbook of Pharmaceutical Exipients, 6th ed. Pharmaceutical Press, UK.

Shafiq-un-Nabi, S., Shakeel, F., Talegaonkar, S., Ali, J., Baboota, S., Ahuja, A., Khar, R.K., Ali, M., 2007. Formulation development and optimization using nanoemulsion technique: A technical note. AAPS PharmSciTech 8, E12-E17. https://doi.org/10.1208/pt0802028

Streets, A.M., Sourigues, Y., Kopito, R.R., Melki, R., Quake, S.R., 2013. Simultaneous Measurement of Amyloid Fibril Formation by Dynamic Light Scattering and Fluorescence Reveals Complex Aggregation Kinetics. PLoS ONE 8, e54541. https://doi.org/10.1371/journal.pone.0054541

Sweetman, S., 2007. Martindale: The Complete Drug Reference, 35th ed. Pharmaceutical Press, London.

Zhang, Y., Shang, Z., Gao, C., Du, M., Xu, S., Song, H., Liu, T., 2014. Nanoemulsion for Solubilization, Stabilization, and In Vitro Release of Pterostilbene for Oral Delivery. AAPS PharmSciTech 15, 1000-1008. https://doi.org/10.1208/s12249014-0129-4 